\title{
SASTRA DALAM TRADISI PENDIDIKAN ISLAM
}

\author{
Sunhaji \\ Institut Agama Islam Negeri Purwokerto \\ Jl. A. Yani 40-A (+62-281)-635624 Purwokerto 53126 \\ E-mail: a.sunhaji@gmail.com \\ HP. +62-813-2705-6975
}

Abstrak: This article stands on the idea that the spread and progress of Islam along the Indonesian Archipelago is influenced by literary works. They have become an important learning in Islamic boarding schools (Pesantren), which is intended to drive students (santri) not only to memorize al-Qur'an and hadits, but also implement them in their real life. This condition can be seen in in the story telling method, which can develop certain characters through appreciating every aspect of life and learning to reproduce the good sides and avoid the bad ones. In such a condition, literary works can be used as a media, a method, even a strategy of learning.

Abstrak: Tulisan ini diasumsikan dari pola pikir bahwa Islam Nusantara dipengaruhi oleh karya sastra. Karya sastra menjadi pembelajaran penting di pondok pesantren. Kondisi ini dapat dilihat dalam metode pembelajaran kisah yang dapat membentuk karakter melalui penghayataan setiap sisi kehidupan sehingga orang bisa belajar untuk meniru tokoh tersebut apabila baik, juga dapat untuk tidak mengulangi kejadian-kejadian buruk yang ada dalam kisah. Dalam hal ini, karya sastra dapat menjadi media pembelajaran, metode, bahkan strategi pembelajaran.

Kata Kunci: Sastra, Estetika, Islam, Pondok Pesantren, dan Moral.

\section{A. Pendahuluan}

Karya sastra memiliki peranan yang penting dalam sejarah Islam (alFaruqi, 1999: 5). Apabila mengacu pada turunnya al-Qur'an, pada masa itu, di Arab sedang mencapai puncak kejayaan seni memainkan kata. Siapapun yang mampu membuat karya sastra akan dianggap sebagai "intelektual". Mereka berlomba-lomba untuk menulis karya paling hebat. Oleh karena itu, al-Qur'an diturunkan dengan tingkat estetika dan etika yang melampaui karya sastra termasyhur di Arab pada saat itu, yakni dengan tingkat kebenaran yang melampaui 
ruang dan waktu. Berdasar pada fenomena ini, untuk memahami ranah simbolik yang ada di dalam al-Qur' an juga dapat ditinjau dari aspek bahasa yang puitis (Murata dan Chittick, 2005: xx-xxii). Bahasa pada al-Qur'an yang masih simbolik dipahami oleh umat Islam yang kadang-kadang dipuji keindahannya dalam bentuk sastra.

Dalam perkembangan agama Islam sendiri, isi dari al-Qur'an telah menginspirasikan banyak pemikir, ulama, maupun seniman untuk menulis kitab, maupun karya-karya lainnya (al-Faruqi, 1999: 7). Isi dari kitab (termasuk juga karya sastra) tersebut berdasar pada kebenaran dari al-Qur'an dan Hadis sehingga sedikit demi sedikit agama Islam berkembang dan dapat diterima dalam ranah budaya suatu masyarakat tanpa perlu menggunakan pedang atau kekerasan. Hakikat keindahan dan pesan yang ada di dalam sastra dari para sastrawan kalangan Islam telah membuka mata batin untuk menjadikan Allah SWT sebagai yang paling pantas untuk disembah. Para sastrawan kalangan Islam selalu menjadikan puncak segala sesuatu adalah Allah SWT, maka itu dalam alunan emosi, pembaca akan terbawa pada penemuan tentang esensi Tuhan yang Sebenarnya di dalam hidup ini melalui karya mereka.

Dalam tradisi pendidikan Islam, sastra juga menjadi bagian penting dalam mengungkapkan pesan-pesan kenabian secara tersembunyi. Ada beberapa kisah hidup dari para ulama mengenai pengalaman mistik terkait pada keterpesonaan spiritualitas yang diungkap melalui karya sastra, sebagai misal juga puisi yang ditulis para sufi. Sachiko Murata (2003: ix) mengungkapkan bahwa para pemikir Islam "menulis risalah-risalahnya untuk merangkai sintesis teologis" dengan menggunakan bahasa mereka yang indah. Ajaran mengenai kesejatian diri, pengetahuan, hubungan manusia dengan alam semesta dan Tuhan sering termanifestasi dalam teks-teks sastra untuk kemudian dibaca oleh masyarakat luas. Dengan mengacu pada ranah kesejarahan, filsafat, dan dimensi kehidupan umat Islam yang tidak bisa lepas dari nuansa keindahan al-Qur'an dan Hadis, maka kiranya menarik untuk menilik pada peranan sastra dalam tradisi pendidikan Islam. Bahkan, Sunan Bonang saja pernah menggunakan Suluk sebagai media untuk berdakwah. Selain itu, ada juga Kitab Ta'lim al-Muta'allim yang sangat terkenal oleh umat Islam di Indonesia (khususnya lingkup pondok pesantren) sebagai sumber ilmu pengetahuan.

Dalam tulisan ini, penulis berusaha untuk mengungkap mengenai peranan karya sastra yang berada dalam tradisi dan budaya pendidikan Islam, baik secara langsung maupun tidak langsung. Tulisan ini sekaligus mendasarkan bahwa kaum Muslim dapat mempelajari karya sastra sebagai aktivitas untuk mema- 
hami dimensi kehidupan dan nilai Ketuhanan. Argumentasi tersebut akan ditelusuri dari aspek tekstual dengan berusaha untuk mempertajam penafsiran dalam ranah kesejarahan yang ada selama ini.

\section{B. Islam dan Sastra}

Al-Qur'an dan Hadis ditransformasikan nilai-nilainya oleh ulama untuk disesuaikan dengan pola kehidupan masyarakat sekitar. Tidak jarang, wujud transformasi tersebut masih mengandung unsur-unsur estetis seperti misalnya yang tertera dalam Kitab Iḥyā' 'Ulūm al-Dīn karya al-Ghazāli, ataupun Fuṣuṣ al-Hikam karya Ibn 'Arabì. Belum lagi, kaum sufi yang memuji keindahan alQur'an dan Hadis dengan berbagai macam keindahan dengan nilai tauhid yang sangat dalam. Begitu pula yang muncul dalam doa umat Islam yang puitis dengan menyebut "demi Muhammad" sebelum berdoa sebagai perantara untuk terkabul. Menurut Schimmel (2005: 250), segala hal yang termanifestasi dalam kehidupan orang Islam dari perbendaharaan doa itu diwarisi oleh Nabi Muhammad SAW, para sahabat dan keluarga, dari orang shaleh maupun para wali yang diungkapkan dengan keindahan-keindahan seperti sedang membentuk kerinduan hati manusia yang sangat puitik, dan berbeda dengan bahasa kehidupan sehari-hari.

Hukum Islam sendiri tetap membolehkan karya sastra, sejauh isinya memuat tentang kebenaran dan sejalan dengan nila-nilai al-Qur' an dan Hadis. Sebagai misal, Qasidah "Burdah" karya yang dikenal dengan nilai-nilai keindahannya. Keindahan Qasidah "Burdah" sering dibaca pada saat maulid Nabi, maupun hari-hari besar Islam lainnya (Khariri, 2008: 223). Aspek sastrawi dari qasidah ini dapat diketahui dari segi intrinsik maupun ekstrinsik, yakni memiliki bait-bait, memiliki makna yang multi-interpretable, keindahan rima dan irama, serta memiliki daya imajinasi. Dalam kaitan ini, sejauh sebuah karya memiliki landasan Tauhid dan memiliki substansi dari Allah SWT sebagai Tuhan, dan Muhammad SAW sebagai Nabi, maka pada ranah itulah wujud pendidikan Islam yang disampaikan dengan sisi keindahan akan menarik perhatian orang. Boleh dikatakan bahwa sastra di dalam Islam itu boleh saja, asal kaidah dan esensinya tidak melenceng dari ajaran Islam itu sendiri, yang mana isinya merupakan kebenaran dan bukan dari bisikan jin seperti penyair yang sesat. Oleh karena itu, esensi pendidikan Islam mengalir di dalamnya sebagai proses membentuk perilaku hidup yang harmoni.

Fenomena mengenai unsur kesenian (kesusastraan) di dalam Islam memang kadang sering diperdebatkan dengan surat asy-Syuara tentang penyair yang tidak beriman berada dalam bisikan jin. Ayat tersebut sesungguhnya 
mengarahkan agar nilai-nilai keindahan memiliki konteks yang jelas dengan realitas sebagai bentuk keharmonisan hidup. Dalam hal ini, esensi keindahan haruslah selalu dalam nilai-nilai yang sejalan dengan al-Qur'an dan Hadis agar ut uh dan sejalan dengan dimensi pendidikan. Entitas itulah yang perlu dipahami agar teks tidak berisi dengan berita yang penuh kebohongan-kebohongan belaka.

Islam sendiri selalu mendasarkan pengetahuan dan konsep kehidupan kepada ucapan syahadat, yakni tiada Tuhan selain Allah dan Nabi Muhammad adalah ut usan Allah. Konsep ini menjadi sangat penting dalam mendasari keimanan umat Islam dengan memahami hakikat al-Qur'an dan Hadis dengan pola figurasi yang memiliki nilai edukatif dalam kehidupan sehari-hari. Al-Faruqi (1999: 13) memandang bahwa al-Qur'an adalah "model utama dan tertinggi bagi kreativitas dan produksi estetis." Pendapat ini, senyatanya memang terkandung di dalam al-Qur'an, yang memang turun pada saat Bangsa Arab hidup dalam pertaruhan sastra. Dengan konsepsi al-Qur'an yang memiliki nilai estetis tinggi, tidak mengherankan jika bahasa yang digunakan oleh Nabi Muhammad SAW, juga memiliki nilai estetis dengan nuansa kehalusan kata. Al-Qur'an dan Hadis selanjutnya menjadi pengetahuan penting dalam praktik kehidupan umat Islam, maupun inspirasi bagi para pemikir filsafat, serta menjadi bagian pendidikan.

Esensi tersebut sebenarnya sejalan dengan al-Baqarah ayat 2 berikut ini. Artinya: "Kitab' (al-Qur'an) ini tidak ada keraguan padanya; petunjuk bagi mereka yang bertaqwa ${ }^{2}$."

Dari ayat tersebut, dapat dipahami bahwa keberadaan al-Qur' an merupakan "petunjuk bagi orang bertaqwa". Dalam hal ini, sesungguhnya isi atau kandungan yang ada di dalam al-Qur'an dapat ditransformasikan dalam kitab yang lebih rinci dan maupun teks-teks lainnya.

Kedekatan Islam dengan sastra lebih dapat dicermati secara tidak langsung. Ketakutan orang Islam pada masa menjelang kenabian Muhammad, yakni bangsa Arab yang pandai bersastra dipakai sebagai acuan kewahyuan akan menjadikan kesesatan dalam berpandangan (al-Faruqi, 1999: 33-34). AlQur'an diturunkan kepada Nabi Muhammad dengan unsur keindahan yang sangat tinggi, dan melampaui kemashuran yang ada pada Bangsa Arab. Kehadiran dari al-Qur'an sendiri membuktikan sebagai bukan buat an manusia karena pandangannya dapat melampaui ruang dan waktu. Kehadiran al-Qur'an melampaui sastra Arab yang pernah ada, dengan tetap membentuk norma sastrawi. Keindahan al-Qur'an akan selalu muncul pada orang yang menghayati 
dan mengamalkannya dalam kehidupan sehari-hari. Kelebihan inilah, yang menjadikan al-Qur'an dianggap sebagai mukjizat, terlebih lagi apabila dibaca dengan suara nyaring dan lantang akan dapat menyentuh perasaan orang dengan nilai seni yang tinggi.

Murata dan Chittick (2005: 5) menyebut bahwa al-Qur'an memiliki tujuh tingkatan makna, yakni dari orang biasa akan dengan mudah bisa memahami, sampai pada tingkat ketujuh yang hanya dimengerti oleh Allah saja (bahkan Nabi tidak tahu, yakni contoh alif lam mim). Di dalam al-Qur'an terdapat keindahan, metafora, maupun alegori yang membutuhkan pemaknaan. Konsep pemaknaan itu dilakukan dengan tafsir ataupun juga dengan ta'wil yang membutuhkan pemahaman terhadap konteks, baik konteks ruang, waktu, maupun pada ranah kontekstualisasi dengan kehidupan masa kini. Dengan kaidah-kaidah sastrawi yang ada di dalam al-Qur'an, maka itu memungkinkan proses ijtihad dengan memahami unsur-unsur intrinsik (seperti memahami teks sastra) sebelum membahas pada ranah ruang dan waktu untuk dikontekstualisasikan dengan kehidupan sehari-hari. Al-Qur'an memiliki keketatan bahasa yang apabila diubah atau hilang sedikit saja akan mempengeruhi makna.

Al-Qur'an dengan nilai sakralitas yang seperti itu akan selalu terjaga originalitasnya. Al-Qur'an ditulis dengan menggunakan bahasa Arab dan tidak akan berubah. Kalaupun al-Qur'an diterjemahkan ke dalam bahasa lain, maka tetap mencantumkan bahasa aslinya. Maksudnya, orang tetap bisa merujuk pada wujud asli tersebut. Bahkan, Nabi Muhammad SAW saja, tetap menggunakan al-Qur'an dalam teks aslinya dalam berdakwah, adapun penafsiran Nabi tentang al-Qur' an lebih disebut sebagai Hadis. Oleh karena itulah, para ulama Islam maupun para pemikir yang hendak mentransformasikan al-Qur'an ke dalam kehidupan yang dialami dan juga masyarakat sekitar, tulisannya disebut kitab (sebagai sebuah karangan tentang kehidupan yang memiliki nilai Islam). Kehadiran kitab yang ditulis oleh ulama maupun pemikir ini tetap tidak menjadikan al-Qur'an sebagai bacaan utama. Orang boleh mempelajari kitab kalau sudah menguasai al-Qur'an.

\section{Pendidikan, Pesantren, dan Sastra}

Pondok pesantren dalam sejarah Islam di Nusantara memiliki peranan yang sangat besar dalam transformasi pengetahuan. Hal ini karena keberadaan pondok pesantren di Nusantara telah membentuk sistem pembelajaran mengenai pengetahuan agama yang dikontekstualisasikan dengan kehidupan sehari-hari. Dalam pembelajaran ini, juga tidak jarang menjadikan karya sastra sebagai usaha untuk menyampaikan nilai-nilai Islam. Sebagaimana yang 
dikatakan oleh Abdul Hadi W.M. (2004: 102), “dalam sejarah pemikiran di Melayu-Nusantara bukan saja karena gagasan tasawufnya, tetapi juga karena karangan, dan puisi-puisi yang mencerminkan semangat pengembaraan spiritual." Oleh karena itu, dari pondok pesantren, muncul syekh dan beberapa kiai yang menulis karya sastra sebagai pengetahuan dan wawasan mereka terhadap agama Islam.

Pembelajaran utama mengenai al-Qur'an dilakukan di pondok pesantren oleh para santri tanpa pandang bulu, sementara mereka yang belajar kitab dilakukan dalam keadaan tertentu, yakni dapat belajar hal lain untuk memperdalam pengetahuan agama. Al-Qur'an dipelajari dengan cara dihafalkan sedikit demi sedikit hingga 30 juz, namun juga dikaitkan dengan fenomena kehidupan di sekitarnya. Pada sisi inilah, menurut Kuntowijoyo (2006: 6-8) dengan membentuk kasadaran ketuhanan dan kesadaran kemanusiaan, seseorang dapat memperluas ruang batin dengan menghayati kehidupan secara langsung maupun tidak langsung. Dalam gagasan lebih lanjut, ia menjelaskan bahwa melalui al-Qur'an dan Hadis, manusia mendalami nilai ketuhanan, sedangkan melalui karya sastra manusia dapat mengaitkannya dengan kehidupan yang ada di sekitarnya.

Tent unya, pembelajaran karya sastra dilakukan setelah pembelajaran alQur'an. Di pondok pesantren, pembelajaran al-Qur'an dilakukan dengan menjadikan par santri hafal: dengan ketentuan tajwidnya telah sesuai agar makna tidak ada yang keliru. Setelah itu, mereka baru diperbolehkan untuk mempelajari kitab-kitab yang lain, yang memberikan penjelasan antara alQur'an dengan kehidupan sehari-hari. Maksud pembelajaran kitab lain di pondok pesantren agar para santri kelak di masyarakat tidak menjadi orang kaku yang hanya tahu cara menghafal al-Qur'an saja, tetapi mereka juga memiliki penghayatan terhadap kandungan di dalam al-Qur'an dan Hadis. Dalam sejarah Jawa, menurut Suparjo (2014:19-20), Sultan Agung mengembangkan "tiga jenjang pendidikan, yakni pengajian al-Qur'an tingkat desa, pengajian kitab tingkat kawedanan, dan pengajian tingkat kabupaten." Pola dan model pembelajaran al-Qur' an terlebih dulu, baru kitab, dan kehidupan umum juga senyatanya dilakukan di pondok pesantren salaf. Artinya, pembelajaran tentang Ketuhanan menjadi milik pribadi, sedangkan pembelajaran tentang kemanusiaan menjadi ranah kebersamaan.

Pembelajaran penghayatan tidak sama dengan belajar menghafal, hanya saja sebenarnya keduanya memiliki keterkaitan bila dicermati secara mendalam. Ilmu yang telah dihafalkan oleh manusia akan hilang dengan sendirinya tanpa ada pengamalan dalam kehidupan sehari-hari. Selain itu, untuk melakukan 
amalan, juga dibutuhkan ilmu agar setiap pola perilaku tidak keliru dalam mengambil keputusan. Penghayatan akan memperdalam ilmu yang telah diraih oleh seseorang dengan pemahaman yang baik sehingga mampu menyelami setiap nilai yang terkandung di dalamnya. Nilai adalah segala sesuatu yang dipentingkan manusia sebagai subjek, menyangkut segala sesuatu yang baik atau buruk sebagai abstraksi, pandangan, atau maksud dari berbagai pengalaman dengan seleksi perilaku yang ketat. Dari pendapat tersebut dapat dikatakan, bahwa dalam kehidupan masyarakat nilai merupakan sesuatu untuk memberikan tanggapan atas perilaku, tingkah laku, dan segala sesuatu yang berkaitan dengan aktivitas masyarakat baik secara kelompok maupun individu. Menurut Sztompka (2007: 109), nilai juga muncul dalam perilaku-perilaku sosial bagi manusia. Adanya pembedaan tingkah laku baik dan buruk menjadi nilai tersendiri bagi seseorang. Dalam ranah kemasyarakatan, nilai menjadi ciri dari perilaku seseorang dalam bergaul dan berinteraksi dengan sesama. Oleh karena itu, muncul beragam nilai terkait dengan kehidupan seseorang di masyarakat.

Dalam perkembangan Islam di Nusantara, pembelajaran kitab di pondok pesantren ada tiga, yakni yang berbentuk rekaan, sejarah, dan kitab yang berporos pada ilmu Islam seperti fiqih, tasawuf, kalam, tarikh, dan tokoh historis (Thoha, 2002: 18). Pengkajian kitab tersebut dilakukan dengan metode bandongan, sorogan, maupun klasikal. Dalam pandangan semacam ini, sastra di pondok pesantren justru menjadi metode pembelajaran sekaligus juga dapat menjadi strategi pembelajaran. Sastra sebagai metode pembelajaran diarahkan agar para santri memiliki kemampuan untuk menafsirkan atas fenomena kehidupan. Dengan kata lain, ada upaya untuk pengenalan at as berbagai macam kejadian untuk diambil hikmaknya. Adapun sastra sebagai strategi pembelajaran diimplementasikan sejalan dengan nilai-nilai yang ada di dalam al-Qur'an dan Hadis. Sebagai contoh, ada Hikayat Amir Hamzah yang ditulis untuk menjadikan pembaca merasa memperdalami ilmu agama Islam dalam kehidupannya. Contoh lain adalah suluk dari Sunan Bonan yang dijadikan sebagai media untuk menjadikan orang Jawa masuk Islam.

Dari tradisi belajar sastra di pondok pesantren, ini ada juga pondok pesantren yang yang menjadikan menulis sebagai tradisi. Sebagai contoh, tradisi menulis kitab oleh KH. Hasyim Asy'ari yang berkaitan dengan aqidah akhlak, fikih, dan pendidikan anak (Nata, 2013: 319). Belum lagi tokoh-tokoh penulis yang berasal dari pondok pesantren seperti Amir Hamzah, Hamka, Raja Ali Haji, yang karya-karyanya memiliki semangat Islam (Hadi W.W., 2004: 204207). Dengan karya-karya yang memuat nilai-nilai Islami, senyatanya akan 
jauh lebih menarik untuk dipelajari dan membentuk sistem nilai sebagai karakter hidup.

\section{Pendidikan Islam melalui Sastra}

Menurut Subur (2014: 48), pedidikan Islam melalui karya sastra diimplementasikan dengan model penanaman nilai yang tersembunyi di dalam kisah. Konsep seperti ini sebenarnya juga telah mewujud dengan peranan sejarah Islam itu sendiri yang selalu menyimpan hikmah. Bahkan, bila dikaji secara mendalam, sebagian dari isi di dalam al-Qur'an adalah kisah-kisah kehidupan, yang mana manusia di zaman Nabi Muhammad SAW ini diarahkan untuk bisa belajar dari kisah-kisah yang sudah ada sebelumnya. Kisah menjadi penelurusan jejak kehidupan yang ada dengan berusaha mengungkap kejadian secara runt ut dengan pembaca berusaha untuk memetik hikmah yang tersembunyi di dalamnya.

Dengan hadirnya karya sastra yang membicarakan persoalan manusia, antara karya sastra dengan manusia memiliki hubungan yang tidak terpisahkan. Sastra dengan segala ekspresinya merupakan pencerminan dari kehidupan manusia. Adapun permasalahan manusia merupakan ilham bagi pengarang unt uk mengungkapkan dirinya dengan media karya sastra. Hal ini dapat dikatakan bahwa tanpa kehadiran manusia, baik manusia sebagai sastrawan maupun sebagai penikmat sastra. Mencermati hal tersebut, jelaslah manusia berperan sebagai pendukung yang sangat menentukan dalam kehidupan sastra. Karya sastra adalah suatu kegiatan kreatif sebuah karya seni. Sastra merupakan segala sesuatu yang ditulis dan tercetak. Selain itu, karya sastra juga merupakan karya imajinatif yang dipandang lebih luas pengertiannya daripada hanya rekaan semata (Wellek dan Werren, 1993: 3-4 ).

Pada ranah tersebut, ada ranah estetika bergerak pada wilayah manifestasi sublimatif karena adanya transformasi pada bentuk, isi maupun efek. Sublimasi bentuk karena adanya keindahan yang tampak pada bentuk bahasa (bila seni lain, yakni dalam wilayah lahir) yang dalam pandangan mata, dan telinga tampak indah. Sublimasi isi karena adanya keindahan dalam hakikat terdalam, yang diwadahi bentuk untuk dinikmati. Adapun sublimasi efek karena adanya dinamisasi antara bentuk dan isi sehingga memunculkan efek untuk mempengaruhi kesadaran dalam memunculkan persepsi. Adanya sublimasi tersebut membuat keindahan, tidaklah sekadar indah wilayah luaran saja, namun keindahan itu masih pada wilayah dalam. Keindahan-keindahan antara luar dan dalam terjalin dalam kompleksitas yang saling mendukung sebagai aksentuasi teks. Untuk mencapai dua keindahan tersebut, perlu adanya 
sublimasi dalam bentuk, isi, maupun efek. Sublimasi tersebut tampak nyata dengan adanya pola-pola baru yang interaktif di dalam teks sebagai estetika. "Seorang penulis Muslim yang benar-benar memahami estetika Islam akan mengerti bahwa keindahan tertinggi yang ingin dicapai dalam karyanya terkait dengan pengalaman spiritual" (Hadi W.M., 2004: 207-208).

Pengalaman spiritual dari yang dialami oleh seseorang berdasarkan hubungan dengan Tuhan akan menjadi pengetahuan. Pengetahuan tersebut dapat memberikan pencerahan kepada orang yang membaca unt uk turut mendalami kehidupan. Penulis Muslim biasanya memandang seni (baca: sastra) Islam sangat terkait dengan tasybih yang menjadi visi dan eksistensi Allah di dunia ini (Murata dan Chittick, 2005: 444). Wilayah representasional ini adalah pengetahuan yang penting untuk dipelajari dalam unsur-unsur manusiawi terkait dengan proses pembelajaran dalam hidup.

Dalam paradigma pendidikan, kisah dari karya sastra juga menjadi metode untuk menyampaikan pesan, bahkan ajaran. Kejadian yang ada dalam sebuah kisah dapat menjadi pembelajaran menarik (agar meniru atau bahkan agar tidak mengalami kejadian yang serupa). Ada unsur konstruksi ketaksadaran pada sebuah kisah yang secara perlahan dapat menjadi sistem nilai bagi jiwa manusia (Subur, 2014: 48). Kisah dapat menjadi cerminan bagi pembaca untuk menjalani hidup serupa dengan tokoh yang ada di dalamnya. Selain itu, kisah menyajikan pesan yang dapat mempengeruhi emosi kejiwaan dalam sebuah amanat. Dalam kaitan ini, biasanya, orang yang membaca kisah atau mendengarkan suatu kisah akan terinspirasi dari isi yang ada di dalamnya.

Kesadaran orang Islam mengenai kisah-kisah yang telah ada dipahami dan dikaji dengan mengaitkan kepada kehidupan pada masa sekarang. Tujuan dari penceritaan ulang agar orang itu belajar untuk menemukan jawaban atas keserupaan kejadian yang sedang dialami. Dalam kehidupan ini, memang kenyataan selalu berubah sesuai dengan kondisi, namun pola munculnya permasalahan sebenarnya memiliki keserupaan. Sebagai contoh, kisah anak durhaka pada anak Nabi Nuh AS, kisah orang-orang yang lebih suka dengan sesama jenis ada pada Nabi Luth AS. Bahkan, terkadang para kiai sengaja mengambil kisah di dalam kehidupan sekitar sebagai materi dakwah agar orang yang mendengar dapat terinspirasi. Pesan-pesan kenabian yang seperti itu apabila tertuang dalam karya sastra disebut sebagai "Sastra Profetik".

"Sastra Profetik mempunyai kaidah-kaidah yang memberi dasar kegiatannya, sebab ia tidak saja menyerap, mengekspresikan, tetapi memberi arah realitas. Sastra Profetik adalah juga sastra dialektik, artinya sastra yang berhadaphadapan dengan realitas, melakukan penilaian dan kritik sosial-budaya secara 
beradab. Oleh karena itu, Sastra Profetik adalah sastra yang terlibat dalam sejarah kemanusiaan. Ia tidak mungkin terpencil dari realitas. Akan tetapi, sastra hanya bisa berfungsi sepenuhnya bila ia sanggup memandang realitas dari suatu jarak, karena itulah lahir ungkapan, "sastra lebih luas dari realitas", "sastra membawa manusia keluar dari belenggu realitas", at au "sastra membangun realitasnya sendiri". Ia adalah renungan tentang realitas. Realitas sastra adalah realitas simbolis bukan realitas aktual dan realitas historis. Melalui simbol itulah sastra memberi arah dan melakukan kritik" (Kuntowijoyo, 2006: 1-2).

Dari petikan tersebut, dapat dipahami esensi karya sastra yang dapat menjadi bahan pelajaran nilai-nilai Islami, yakni berdialektika dengan realitas dan memberi "arah" dan melakukan kritik. Pada sisi inilah, sesungguhnya tertanam nilai, yang ketika dibaca oleh masyarakat akan terserap sebagai pengetahuan. Oleh karena itu, teknik pengucapan dalam karya sastra yang sejatinya sering diperagakan oleh para kiai dalam berceramah menjadi strategi dan metode mereka untuk menyampaikan nilai-nilai Islami. Dari nilai-nilai itulah, pada nantinya yang akan menjadi karakter dalam pergulatan manusia di tengah peradaban.

Pendidikan karakter menjadi suatu sistem penanaman nilai-nilai karakter kepada warga sekolah yang meliputi komponen pengetahuan, kesadaran atau kemauan, dan tindakan untuk melaksanakan nilai-nilai tersebut. Pendidikan karakter dapat dimaknai sebagai usaha untuk menciptakan kecerdasan emosional dan intelektual yang seimbang. Dalam pendidikan karakter di sekolah, semua komponen (pemangku pendidikan) harus dilibatkan, termasuk komponen-komponen pendidikan itu sendiri, yaitu isi kurikulum, proses pembelajaran dan penilaian, penanganan atau pengelolaan mata pelajaran, pengelolaan sekolah, pelaksanaan aktivitas atau kegiatan ekstrakurikuler, pemberdayaan sarana prasarana, pembiayaan, dan etos kerja seluruh warga sekolah/lingkungan. Di samping itu, pendidikan karakter dimaknai sebagai suatu perilaku warga sekolah yang dalam menyelenggarakan pendidikan harus berkarakter. Menurut Kementrian Pendidikan dan Kebudayaan, (2012: 5), pendidikan juga harus memberikan dasar bagi keberlanjutan kehidupan bangsa dengan segala aspek kehidupan bangsa yang mencerminkan karakter bangsa masa kini. Oleh karena itu, konten pendidikan yang mereka pelajari tidak semata berupa prestasi besar bangsa di masa lalu tetapi juga hal-hal yang berkembang pada saat kini dan akan berkelanjutan ke masa mendatang.

Melalui karya sastra dengan nilai Islami, seseorang diarahkan untuk menghargai dan menghayati perilaku jujur, disiplin, tanggung jawab, peduli 
(toleransi, gotong royong), sant un, percaya diri, dalam berinteraksi secara efektif dengan lingkungan sosial dan alam dalam jangkauan pergaulan dan keberadaannya. Ada juga anjuran untuk memahami pengetahuan (faktual, konseptual, dan prosedural) berdasarkan rasa ingin tahunya tentang ilmu pengetahuan, teknologi, seni, budaya terkait fenomena dan kejadian tampak mata. Untuk menghargai adanya perbedaan juga diajarkan mengenai mencoba, mengolah, dan menyaji dalam ranah konkret (menggunakan, mengurai, merangkai, memodifikasi, dan membuat) dan ranah abstrak (menulis, membaca, menghitung, menggambar, dan mengarang) sesuai dengan yang dipelajari di sekolah dan sumber lain yang sama dalam sudut pandang/teori.

\section{E. Simpulan}

Dari uraian-uraian yang ada di dalam pembahasan, dapat disimpulkan mengenai beberapa hal berikut ini. Pertama, Islam mengarahkan agar karya sastra memiliki keberimbangan antara imajinasi dan kebenaran sehingga bukan sebuah lamunan palsu dari bisikan jin. Kisah yang ada di dalamnya merupakan realitas yang benar. Kedua, dengan orang terbiasa memahami bahasa karya sastra yang penuh dengan perumpamaan, dimungkinkan juga dapat memahami esensi dari makna yang terkandung di dalam al-Qur'an dan Hadis yang memang masih menggunakan bahasa simbolik. Ketiga, para pemikir dari kaum Muslim sering memuji keindahan yang ada di alam semesta ini dengan berdasar pada al-Qur'an dan Hadis dengan maksud ketika dibaca oleh orang akan menguatkan nilai-nilai spiritualitas mereka. Keempat, karya sastra dipelajari di pondok pesantren sebagai pengetahuan tambahan untuk menjadikan para santri dapat menghayati kehidupan. Selain itu, karya sastra dapat dijadikan sebagai media, metode, maupun sebagai strategi pembelajaran. Hal ini dapat diwujudkan dengan nilai-nilai yang bisa dipetik dari kisah di dalamnya, yang dapat membangkitkan emosi dan dimensi kesadaran dari pembaca.

\section{Daftar Pustaka}

Al-Faruqi, Ismal Raji. 1999. Seni Tauhid: Esensi dan Ekspresi Estetika Islam (Cultural Atlas of Islam) diterj. oleh Hartono Hadikusumo. Yogyakarta: Yayasan Bentang Budaya.

Corbin, Henry. 2002. Imajinasi Kreatif Sufisme Ibn 'Arabì (L'Imagination cretrice dans le Soufisme d'Ibn 'Arabī) diterj. oleh Moh. Khozim dan Suhadi. Yogyakarta: LKiS. 
Hadi W.M., Abdul. 2004. Hermeneutika, Estetika, dan Religiusitas: Esai-esai Sastra Sufistik dan Seni Rupa. Jakarta: Paramadina.

Kementrian Pendidikan dan Kebudayaan. 2012. Dokumen Kurikulum 2013. Jakarta: Kementrian Pendidikan dan Kebudayaan.

Khariri. 2008. Islam dan Budaya Masyarakat. Purwokerto: STAIN press.

Kuntowijoyo. 2006. Maklumat Sastra Profetik. Yogyakarta: Grafindo Litera Media.

Murata, Sachiko. 2003. Kearifan Sufi dari Cina (Cchinese Gleams of Sufi Light) diterj. oleh Susilo Adi. Yogyakarta: Kreasi Wacana.

Murata, Sachiko dan William C. Chittick. 2005. The Vision of Islam diterj. oleh Suharsono. Yogyakarta: Suluh Press.

Nata, Abuddin. 2013. Kapita Selekta Pendidikan Islam: Isu-isu Kontemporer tentang Pendidikan Islam. Jakarta: Raja Grafindo Persada.

Schimmel, Annemarie. 2005. Mengurai Ayat-ayat Allah (Deciphering the Ssigns of God: A Phenomenological Approach to Islam) diterj. oleh M. Khoirul Anam. Depok: Inisiasi Press.

Subur. 2014. Model Pembelajaran Nilai Berbasis Kisah. Purwokerto: STAIN Press.

Suparjo. 2014. Komunikasi Interpersonal Kiai-Santri: Keberlangsungan Tradisi Pesantren di Era Modern. Purwokerto: STAIN Press.

Thoha, Zainal Arifin. 2002. Eksotisme Seni Budaya Islam. Yogyakarta: Buku Laela.

Stompka, Piotr. 2007. Sosiologi Perubahan Sosial. Jakarta: Prenada.

Wellek, Rene dan Austrin Warren. 1993. Teori Kesusastraan. Melani Budianta (Terj.) Jakarta: Gramedia. 